\title{
Analysis of Problem Solving Ability and Creative Thinking Ability of Mathematic Students Through the Application of the Problem Based Learning Model in Class VIII Students of Smp Jendral Sudirman Medan
}

\author{
Hendrikson R Panjaitan* Asrin Lubis Waminton Rajagukguk \\ Department of Mathematics, Science Faculty, State University of Medan, Jl. William Iskandar Ps. V, Kenangan
}

Baru, Sumatera Utara Indonesia

\begin{abstract}
This study aims to: 1) To improve students 'mathematical problem solving abilities taught by using the Problem Based Learning model 2) To improve students' mathematical creative thinking skills taught by using Problem Based Learning models 3) To analyze the number of difficult indicators of problem solving abilities and mathematical creative thinking of students who taught using the Problem Based Learning model. Subjects in this study involved 38 students from Jendral Sudirman Medan Class VIII students who were treated with Problem Based Learning in the even semester of 2019/2020 with 38 students. The results showed that: 1) Mathematical problem solving abilities of students with problem based learning models. There were 11 good ability students (28.94\%), 8 enough ability students (21.05\%), and 19 less ability students (50\%). 2) Whereas students' mathematical creative thinking abilities with problem based learning models. There were 8 students with high ability (21.05\%), 6 students with medium ability (23.68\%), and 21 students with low ability (55.26\%). 3) Students who have high mathematical creative thinking with a score of 93.75 have good categorical problem solving skills with a score of 93.75 . Students who have medium creative thinking with a score of 75 have enough categorical problem solving abilities with a score of 68.75. And students who have low creative thinking with a score of 43.75 have less ability to solve categorical problems with a score of 50 .
\end{abstract}

Keywords : mathematical problem solving abilities, mathematical creative thinking abilities, Problem Based Learning,

DOI: $10.7176 / \mathrm{JEP} / 11-17-07$

Publication date:June 30th 2020

\section{Introduction}

Learning is the process of interaction with all situations that exist around the individual. Learning can be seen as a process that is directed towards goals and the process of acting through various experiences (Rusman, 2012: 1). Learning is also a process of seeing, observing and understanding something (Syah, 2013: 62). Therefore, a correct understanding of the meaning of learning with all aspects, forms and manifestations is absolutely necessary for the teacher. Errors or incompleteness of their perceptions of the learning process and matters related to it will result in the quality of the development index in Indonesia is still very low. This can be seen from the Human Development Index (HDI) data released by UNDP (United Nations Development Program), which is the composition of education, health and per capita income ranking which shows that Indonesia's human development index is still ranked below the world. Among all countries in the world, Indonesia ranks 102nd in 1996. In 1997, Indonesia ranked 99th. 1998 ranked 105th. 1999 ranked 109th. Year 2007 ranks 111 th. 2011 ranked 124th. 2012 ranks 121nd and 2013 ranks 108th (Purwananti, 2016: 221).

To improve the Indonesian human development index, we need a material that is taught and studied at every level starting from elementary school (SD) to tertiary institutions, namely mathematics. Mathematics is a universal science that underlies the development of technology and has an important role in various scientific disciplines and advancing human thought power. Hasratudin (2018:159) argues that mathematics is a product of human intellectual thinking. Intellectual thinking is usually driven from problems involving daily real life. Such mathematics is also referred to as human life and a means to train thinking. It turns out that not only that, Eviliasani, Hendriana and Sanjayawati (2018: 334) that mathematics is taught is basically aimed at students' mindsets so that they can solve problems and are creative, critical, logical, analytical, systematic, and have the ability to work together.

But in reality, according to Rahmawati (2014: 75) explains that student achievement in mathematics has not been very satisfying both at the National and International levels. The achievements of Indonesian students at the International level are still behind compared to other countries. This can be seen from the results of the World Competitiveness Year Book survey, Indonesia is in the 37th level of 60 countries (IMD WCY, 2014: 3). Conditions that are not much different can be seen from the results of studies conducted by PISA (Program for International Student Assessment) and TIMSS (Trends International Mathematics and Science Study).

Being aware of this, problem solving ability is one of the important abilities students must have. Problem 
solving according to Anderson (2009) is a life skill that involves the process of analyzing, interpreting, reasoning, predicting, evaluating and reflecting. So, problem solving ability is the ability to apply previously owned knowledge to new situations that involve higher-order thinking processes.

Problem solving also requires thinking activities so that he is able to understand the mathematical concepts learned and be able to use these concepts appropriately when students need to find answers to various mathematical problems. Mathematical problems are not easy to find solutions while students are expected and demanded to be able to solve these problems. Therefore, students need to have thinking skills in order to find the right way to solve the problems they face.

But in reality, the problem-solving ability of learning mathematics is still low. It can be seen from the results of Atun's research (2006) that the acquisition of pre-test for the ability to solve mathematical problems in the experimental class reached an average of 25.84 or $33.56 \%$ of the ideal score. Likewise, the results of Agustina's research (2011) revealed that the acquisition of pre-test for the ability to solve learning from 32 students, only 18 students had completed learning or $56.25 \%$ of the total number of students.

$\mathrm{n}$ addition to problem solving skills, one of the important abilities possessed by students is the ability to think creatively. Hevy (2017: 3861) argues that "Creative thinking is very important in the current global era is needed when the complexity of problems from all aspects of life. In creative thinking there are two basic components needed, namely the balance between logic and intuition.

But in reality, students' creative thinking abilities are quite alarming. As Munandar (2012: 73) says that "Indonesian students rank lowest in the creativity scores in creative thinking tests that are followed by eight countries". The low creative thinking in students 'mathematics, shown in research conducted by Purba (2017: 267-268) found that the level of creative thinking skills in mathematics of 50 students with' very low 'creative thinking abilities as much as $38 \%$ and creative thinking skills' very high 'only as much as $4 \%$.

To have good problem solving skills and creative thinking in learning is not easy, but problem solving skills and creative thinking can be learned and trained. Therefore, teachers must find learning that can involve students in problem solving skills and creative thinking. There are many learning models that can be used in efforts to develop problem solving abilities and mathematical creative thinking. One model of learning that is thought to be in line with the mathematical characteristics and curriculum expectations that apply at this time is the Problem Based Learning model. Problem Based Learning Model is an approach to student learning in authentic (real) problems so students can compile their own knowledge, develop high skills and inquiry, independent

Piaget (2008: 123) says the Problem Based Learning model in which the teacher gives a variety of situations (problems) so students can experiment, try out various things to see what will happen, manipulate objects, manipulate symbols, throw questions and find answers themselves, conciliate what is found and compare it with the findings of other students. Meanwhile, according to Arends (2008: 134) that Problem Based Learning has the essence of presenting various real problematic conditions, which will later be solved by students through various investigations and investigations. The role of the teacher is to present a variety of contextual problems with the aim of motivating students, arousing student enthusiasm, increasing student learning activities, learning focused on problem solving so students are interested in learning, finding concepts and sharing knowledge between students and students, students and teachers. Therefore, it can be concluded that the Problem Based Learning model is learning that uses real world problems as a context for students to learn critical thinking and problem solving skills, as well as to obtain essential knowledge and concepts from the subject matter.

\section{Methods \\ Research Pattern}

This research is a descriptive study using a qualitative approach. Qualitative research is research that intends to understand phenomena about what is experienced by research subjects such as behavior, perceptions, actions and others without generalizing what is obtained from research (Herdiansyah, 2012).

\section{Participants}

The subjects in this study involved 38 students from Jendral Sudirman Medan Class VIII who were given Problem Based Learning in the even semester of the 2019/2020 academic year with 38 students.

\section{Data Collection Technique}

This data collection process includes the process of entering the research site as well as being in the research location and collecting research data. Data collection techniques in this research is the survey method. These instruments include tests of problem solving skills, mathematical creative thinking and interview guidelines. data triangulation, and documentation in the form of photos, sound recordings and video recordings.

\section{Validity and Reliability}

Validation of learning devices and instruments aims to obtain valid learning instruments and research 
instruments that are suitable for use in research. Learning devices and research instruments are validated by 5 experts. Based on the results of the learning device validation it was found that learning devices were good for use in learning. the validation of the research instruments was carried out statistical tests (empirically) to see the validity, reliability so that the validity of the research instruments was getting better.

\section{Data Analysis}

Analysis of the data used in this study, namely qualitative data analysis. Qualitative analysis is used to analyze data on the results of tests of problem solving abilities and the results of mathematical creative thinking tests of students collected to be examined and scored according to scoring guidelines. The qualitative approach used in this study follows the concept given by Mile and Huberman consisting of three activities that occur interactively and continue continuously until completion. Data analysis in qualitative research is carried out at the time the data collection takes place, and after the data collection is completed within a certain period. At the time of the interview, the researcher has done an analysis of the answers interviewed after the analysis felt unsatisfactory, the researcher will continue the question again to a certain stage so that credible data is obtained. After the researchers have collected data, the researchers anticipate it before carrying out data reduction. Actually, before the data is actually collected, there will be a reduction in data anticipation when the researcher decides on the conceptual framework, the research area, the research problem and the data collection approach to be chosen. After that the data is presented and conclusions can be drawn.

\section{Result and Discussion}

1) Description of Students' Mathematical Problem Solving Ability

In the following table 4.1 the percentage of test results for problem solving ability based on the high, medium and low categories will be presented.

Table 4.1. Test the Level of Students Mathematical Problem Solving Ability

\begin{tabular}{|c|c|c|c|c|}
\hline No & Value Interval & Total students & Percentage & Rating Category \\
\hline 1 & $80 \leq$ SMPSA $\leq 100$ & 11 & $28,94 \%$ & Good \\
\hline 2 & $65 \leq$ SMPSA $<80$ & 8 & $21,05 \%$ & Enough \\
\hline 3 & $0 \leq$ SMPSA $<65$ & 19 & $50 \%$ & Less \\
\hline
\end{tabular}

Note: SMPSA = Students Mathematical Problem Solving Ability

Based on table 4.2 it can be seen the level of students' mathematical problem solving ability with a problem based learning model. There were 11 good students $(28.94 \%), 8$ capable students $(21.05 \%)$, and 19 less capable students $(50 \%)$.

\section{2) Description of Students' Creative Thinking Abilities}

In table 4.3 the following will be presented. The following will be presented percentage test results on the level of creative thinking ability based on high, medium, and low categories.

Table 4.7. Test the Level of Students Mathematical Creative Thinking Ability

\begin{tabular}{|c|c|c|c|c|}
\hline No & Value Interval & Total students & Percentage & Rating Category \\
\hline 1 & $80 \leq$ SMCTA $\leq 100$ & 8 & $21,05 \%$ & High \\
\hline 2 & $65 \leq$ SMCTA $<80$ & 9 & $23,68 \%$ & Medium \\
\hline 3 & $0 \leq$ SMCTA $<65$ & 21 & $55,26 \%$ & Low \\
\hline
\end{tabular}

Note: SMCTA = Students Mathematical Creative Thinking Ability

Based on table 4.4 it can be seen the level of mathematical creative thinking ability of students with problem based learning models. There were 8 students with high ability $(21.05 \%), 6$ students with medium ability (23.68\%), and 21 students with low ability (55.26\%).

\section{3) Description of Indicators Problem Solving and Mathematical Creative Thinking Are Dominant Increased in Learning}

Based on research data that for each category of problem-solving abilities (good, sufficient, lacking), students have at least 1 indicator of creative thinking which is the most dominant which varies between students. In the category of students who have good problem solving abilities, the dominant mathematical creative thinking indicator that is most obtained from 8 students is the Flexibility indicator, which is 4 students. In the category of students with sufficient problem solving abilities, the dominant mathematical creative thinking indicator that is most obtained from 8 students is the fluency indicator and the originality indicator, each of which is 4 students. And in the category of students with less problem solving abilities, the dominant mathematical creative thinking indicator most obtained from 19 students is the Originality indicator, as many as 8 students.

Based on these data it can also be said that the Originality indicator is the most dominant indicator obtained by students. That is, students are the most dominant in solving problems in their own way or able to provide other ways of solving mathematical problems provided.

4) Analysis of the Difficulties in Solving Students 'Mathematical Problem-Solving Abilities and the 


\section{Students' Creative Mathematical Thinking Abilities in Mathematics}

Difficulties in students' creative thinking processes in learning problem based learning while working on problems. To analyze it, several students were taken to represent each category. In the high category, students do not experience significant difficulties in solving the given problem. In the medium category, students have difficulty completing the questions given. In the low category, students have difficulty writing down what is known and asked in the problem, understanding the problem contained in the problem.

The difficulty of students' problem solving processes in learning problem based learning when working on problems. To analyze it, several students were taken to represent each category. In either category, students can easily understand the given problem well. In the sufficient category, students can already understand the problem well, but it is still wrong at the final solution. In the lacking category, students find it very difficult to understand the questions given.

\section{Discussion}

This research focuses analysis on the process of problem solving abilities and students' mathematical creative thinking. Research conducted by Marzuki (2012) with the title Differences in Problem Solving Ability and Mathematical Communication between Students who are given Problem Based Learning with Direct Learning. His research first developed a problem-based learning tool with the 4-D model. The results of his research concluded that (1) the problem-based learning tool developed was included in the valid category; (2) There are differences in problem solving abilities and mathematical communication between students who are given a problem based learning model and students who are given a direct learning model.

Romberg and Fennema (2009), University of Wisconsin Madison and University of Massachusetts Darmouth, entitled Mathematics Worth Teaching, Mathematics Worth Understanding which emphasizes that students not only know the concepts and procedures for some parts of mathematics, but also understand how mathematics is made and used. It even says philosophy that simultaneously emphasizes knowledge and common sense, integration through application, and innovation through creativity.

Savery (2006), University of South Carolina entitled Overview of Problem Based Learning said that learning with the Problem Based Learning (PBL) model of learning has been used successfully for 30 years and continues to receive acceptance in various disciplines. This summary presents a brief history, followed by a discussion of the similarities and differences between PBL and other experiential approaches to teaching, and identifies several challenges.

This is also in line with research conducted by Prasetiyo (2014), Journal of Education entitled Students Creative Thinking in The Application of Mathematical Problem Based Learning where this study aims to describe students' creative thinking by applying mathematical problem-based learning models. Lubis, Minarni, and Surya (2015), Medan State University Entitled the Improvement of Mathematical Problem Solving Ability and Independence of Junior High School Students Learning Through Problem Based Learning Models. The results showed an increase in the mathematical problem solving ability and independence of junior high school students' learning through problem-based learning models was higher than the increase in mathematical problem solving abilities and learning independence of students who obtained conventional learning models.

The Problem Based Learning model is very helpful for students in improving their problem solving abilities and creative thinking. Rangkuti, et al (2014) Medan State University with the title "Improving the Ability to Understand Concepts and Mathematical Problem Solving of SMK Students through Problem Based Learning" also suggests that problem based learning can be used as an alternative learning model used in primary schools to achieve level thinking competencies high.

From 38 students for problem solving ability with the category of "good" as many as $28.94 \%$ totaling 11 students, the category of "enough" as many as $21.05 \%$ totaling 8 students, and the category of "lacking" as many as $50 \%$ totaling 19 students. On the indicators of students' mathematical problem solving abilities namely (1) indicators understand the problem category assessment "Good" as many as 20 students are able to understand the problem well, (2) indicators plan the problem category assessment "Enough" as many as 9 students are quite capable of analyzing and making problem solving with appropriately, (3) indicators of solving the problem category of assessment "Enough" as many as 9 students were able to solve the problem correctly, (4) indicator of re-examining the category of assessment "Enough" as many as 17 students were quite able to show that the answers given were checked again correctly. Then for creative thinking ability with "low" ability as much as $55.26 \%$ totaling 21 students, "moderate" ability as much as $23.68 \%$ totaling 9 students, and "high" ability as much as $21.05 \%$ totaling 8 students. On the indicators of students' mathematical creative thinking abilities, they are (1) Fluency indicators of the "High" assessment category of 7 students able to provide several ideas or ways of solving problems, (2) Flexibility indicators of the "Medium" assessment categories of 13 students have been able to solve problems from an angle different viewpoints and lead to the correct solution in solving problems but not quite right, (3) Originality indicators for "Medium" assessment categories as many as 20 students are able to solve problems in their own way, (4) Elaboration indicators for "Medium" assessment categories as many 
as 7 students are able develop or enrich ideas in detail. This is in line with Sagala (2015), PPs Medan State University conducted research aimed at one of them analyzing the quality of students' creative thinking abilities in the application of the Concept Learning Model. The results showed the ability to understand mathematical concepts of students who were given quantitative learning was $12.5 \%$ in the high category, $46.9 \%$ in the medium category and $40.6 \%$ in the low category.

\section{Conclusion}

1. Students' mathematical problem solving abilities with problem based learning models. There were 11 good students $(28.94 \%), 8$ capable students $(21.05 \%)$, and 19 less capable students $(50 \%)$. Whereas students' mathematical creative thinking abilities with problem based learning models. There were 8 students with high ability (21.05\%), 6 students with moderate ability (23.68\%), and 21 students with low ability $(55.26 \%)$.

2. Students who have high mathematical creative thinking with a score of 93.75 have good categorical problem solving skills with a score of 93.75. Students who have moderate creative thinking with a score of 75 have sufficient categorical problem solving abilities with a score of 68.75 . And students who have low creative thinking with a score of 43.75 have less ability to solve categorical problems with a score of 50 .

3. Difficulties in students' creative thinking processes in learning problem based learning while working on problems. To analyze it, several students were taken to represent each category. In the high category, students do not experience significant difficulties in solving the given problem. In the medium category, students have difficulty completing the questions given. In the low category, students have difficulty writing down what is known and asked in the problem, understanding the problem contained in the problem.

4. Difficulty of students' problem solving processes in learning problem based learning when working on problems. To analyze it, several students were taken to represent each category. In either category, students can easily understand the given problem well. In the sufficient category, students can already understand the problem well, but it is still wrong at the final solution. In the lacking category, students find it very difficult to understand the questions given.

\section{REFERENCES}

Anderson, J. 2009. Mathematics Curriculum Development and the Role of Problem Bergqvist, Ewa. 2006. Mathematics and Mathematics Education.Two Sides of the Same Coin. Doctoral Thesis, Department of Mathematics and Mathematical statistics, Ume ${ }^{\circ}$ a University.

Ditjen GTK Kemdikbud. 2016. Guru Pembelajar, Modul Matematika SMP dan SMA, Kelompok Kompetensi E. Hasratuddin. 2018. Mengapa Harus Belajar Matematika. Medan: Perc Edira.

Herdiansyah, H. 2012. Qualitative Research Methodology: for the social sciences. Jakarta: Salemba Humanika

Munandar, Utami. 1999. Kreativitas dan Keberbakatan Strategi Mewujudkan Potensi Kreatif dan Bakat. Jakarta : PT. Grasindo.

Prasetiyo. 2014. Prosiding, Berpikir Kreatif Siswa dalam Penerapan Model Pembelajaran Berdasar Masalah Matematika. Jurnal Pendidikan Matematika. STKIP PGRI Sidoarjo, Vol. 2 No. 1.

Rangkuti, Sahat Saragih \& Hasratuddin. 2014. Prosising, Peningkatan Kemampuan Pemahaman Konsep dan Pemecahan Masalah Matematis Siswa SMK melalui Pembelajaran Berbasis Masalah, Jurnal PARADIKMA, Vol. 7 Nomor 3, Hal. 1-10.

Romberg dan Fennema. 2009. Mathematics Classrooms That Promote Understanding. New Jersey: Lawrence Erlabaum Associates, Publisher.

Rusman. 2012. Model-Model Pembelajaran: Mengembangkan Profesionalisme Guru. Jakarta: Rajawali Pers.

Sanjaya, W. 2006. Strategi Pembelajaran Berorientasi Standar Proses Pendidikan. Jakarta: Kencana.

Savery, J. R. 2006. Overview of Problem-based Learning: Definitions and Distinctions, Interdisciplinary Journal of Problem-Based Learning, Volume.1

Solving. ACSA Conference..pdf, diakses 13 Oktober 2013

Trianto. 2011. Mendesain Model-Model Pembelajaran Inovatif-Progresif. Jakarta: Kencana Prenada Media Group.

Sagala, Syaiful. 2009. Konsep dan Makna Pembelajaran. Bandung: Alfabeta 